\title{
Field Performance of Single Cultivars of Tuberose for Growth and Floral Characters under Assam Condition
}

\author{
Kishalayee Gogoi $^{1 *}$ and Madhumita Choudhury Talukdar ${ }^{2}$ \\ ${ }^{1}$ Department of Horticulture, Biswanath College of Agriculture, Assam Agricultural \\ University, Biswanath Chariali \\ ${ }^{2}$ Department of Horticulture, College of Agriculture, Assam Agricultural University, Jorhat \\ *Corresponding author
}

\begin{tabular}{l} 
Ke y w o r d s \\
Assam, Cultivars, \\
Growth parameters, \\
Flower parameters, \\
Tuberose \\
\hline Article Info \\
Accepted: \\
15 March 2020 \\
Available Online: \\
10 April 2020
\end{tabular}

\section{Introduction}

Tuberose (Polianthes tuberosa Linn.) is one of the most important commercial bulbous ornamentals due to its potentiality for cut flower trade, long vase life, essential oil industry, attractive long spikes, high cutflower yield and nearly year round yield in tropical and subtropical climates (Benschop, 1993; Singh, 1995). Tuberose commonly known as 'Rajanigandha' and it belongs to the family Amaryllidaceae and native to Mexico.
Polianthes genus contains three types of flowers one of them is single flower type having basic chromosome number $\mathrm{n}=\mathrm{x}=30$ and $2 n=60$, which is female fertile used in perfumery industry and breeding programme as female parent, semi-double and double type of flower $2 n=50$ and generally used for cut flower (Mahawer et al., 2013). The flowers are used for making garlands, bouquets, floral ornaments and other floral arrangements. Though many cultivars of tuberose can be grown in a particular agro- 
climatic region but all are not suitable for that region for cut flower or maximum production. Among them some are well suited while other performs poorly. So, there is a need for evaluation of cultivars and recommendation of a cultivar best suited for a particular agroclimatic region. Since Assam is agro climatically most suited for growing tuberose, there is a great scope for building up of commercial cut flower market for tuberose in this region. Cut flower industry is still in its infantry in Assam and many growers are still unaware of the importance of tuberose as a cut flower. Therefore there is need to introduce tuberose as a cut flower, source of oil industry and possibly more way towards export in this area. Looking to the potential of some tuberose cultivars there is an urgent need to evaluate them under Assam conditions. To find out the suitable tuberose cultivars in Assam condition this present investigation is undertaken.

\section{Materials and Methods}

The present investigation included 14 genotypes of the species conducted in the Experimental Farm, Department of Horticulture, Assam Agricultural University, Jorhat in two seasons during 2016-17 and 2017-18. The genotypes taken were Arka Nirantara, Mexican Single, Prajwal, Jorhat Collection, Guwahati Single, Hajo Locale, Calcutta Single I, Calcutta Single II, Hyderabad Single, Sikkim Selection, Bidhan Rajani I, Bidhan Rajani II, Shringar and Phule Rajani. The experiment was laid out in randomized block design with three replications. The soil was brought to a fine tilth by giving deep ploughings. The field was divided into plots for allotment of various treatments. Forty two plots were laid out to accommodate all the 14 treatments replicated three times. The gross size of an individual plot was $2.5 \times 1.5 \mathrm{~m}$ in each replication. Medium sized bulbs of $3.0-3.5 \mathrm{~cm}$ diameter weighing about 25 grams were selected and treated with Bavistin $1.5 \mathrm{~g} / \mathrm{l}$ water for half an hour. The treated bulbs were planted in rows at $30 \times 25 \mathrm{~cm}$ spacing accommodating 28 plants per plot. All the growth and flower characters were recorded in five sampled plants in each treatment from each replication. The growth and flower parameters were recorded for two years. The data obtained were statistically analyzed for analysis of variance.

\section{Results and Discussion}

Plant height determines the overall quality and productivity of a plant. Among the single cultivars Arka Niranatara exhibited highest plant height $(104.33 \mathrm{~cm})$ which was at par with Prajwal $(104.33 \mathrm{~cm})$ and Prajwal $(102.00 \mathrm{~cm})$. The minimum plant height was exhibited by Phule Rajani which was at par with Jorhat Collection $(76.83 \mathrm{~cm})$ and Hyderabad Single $(74.00 \mathrm{~cm})$ Table 1. This variation in plant height is may be due to the genotypic differences which resulted in phenotypic expression of the traits and variations in different genotypeenvironmental interaction. Similar results were obtained by Pal and Mitra (2008), Ramachandrudu and Thangam (2009), Singh and Singh (2013), Mahato (2016) and Dimri et al., (2017) in tuberose. The highest leaves per plant was exhibited by Guwahati single (76.33 numbers) which was at par with Hajo Locale (69.00 numbers) and Arka Nirantara (67.50 numbers). The lowest leaves per plant were observed in Sikkim Selection (42.00). The variation in leaf production among the varieties can be attributed to genetic character. Even the environmental factors also determine the production of leaves. This result is in conformity with the findings of Banker and Mukhopadhyay (1980), Pal and Mitra (2008), Chaturvedi et al., (2010), Singh and Singh (2013) and Dimri et al., (2017) in tuberose. After planting bulbs timely 
sprouting of bulbs is very important primary character for the evaluation of better cultivars. Various cultivars showed a significant difference in day's requirement for sprouting. Among the cultivars the minimum days taken to bulb sprouting was exhibited by Arka Nirantara (12.17 days) which was at par with Hyderabad Single (12.50 days),Shringar (12.50 days) and Prajwal (13.50 days). The maximum days to bulb sprouting was exhibited by Guwahati Single (16.50 days). The variations in sprouting period are most probably due to change in climatic conditions of different places and the genetic makeup of the cultivar used. Singh and Jonah(2017) found minimum days to bulb sprouting in $\mathrm{cv}$. Local (5.00 days). Also the minimum days taken to spike emergence was exhibited by Arka Nirantara (74.83 days) which was at par with Hyderabad Single (76.17 days). The maximum days to spike emergence was exhibited by Calcutta Single II (82.16 days). The variation in days taken to spike emergence might be primarily governed by the genetic makeup of the varieties and change in climate. These results were also experimentally supported by the findings of Dimri et al., (2017) and Singh and Jonah (2017) in tuberose.

Among the floral characters spike length is especially desirable for cut flower point of view because large spike will have more number of flowers and most preferred by consumer. The highest spike length was recorded for Arka Nirantara $(87.83 \mathrm{~cm})$ which was at par with Calcutta Single I $(84.17 \mathrm{~cm})$ and Shringar $(83.17 \mathrm{~cm})$. The lowest spike length was recorded for Bidhan Rajani II $(53.67 \mathrm{~cm})$. Similar findings are also reported by Patil et al., (1987) under Pune conditions (80-90 cm spike length) supports present study. Slight differences may be due to the climatic conditions of the different places. Rachis length is another important spike character that was positively and significantly correlative with spike length. Cultivars that have large spike may have large rachis length and they may be considered as best quality spike for cut flower purpose. In present study there were highly significant differences among the cultivars with respect to rachis length. Among the cultivars the highest rachis length was recorded for Arka Nirantara $(59.00 \mathrm{~cm})$ which was at par with Shringar $(54.83 \mathrm{~cm})$ and Prajwal $(51.83 \mathrm{~cm})$. The lowest spike length was recorded for Hajo Locale $(38.16 \mathrm{~cm})$. The variations in rachis length of different cultivars are also might be due their varietal character and climatic condition. This has been confirmed by Ramachandrudu and Thangam (2009) in tuberose. As the number of florets per spike is concerned it is also a very important characteristic of the tuberose which is directly proportional to the yield of the cultivar. When numbers of florets per spike are more it increases weight and attractiveness of the spike. Among the cultivars the highest number of florets per spike was recorded for Arka Nirantaran (36.83) which was at par with Shringar (36.67), Mexican Single (36.33), Calcutta single I(36.00), Bidhan Rajani I(35.16) and Prajwal (35.16). The lowest number of florets per spike was recorded for Sikkim Selection (23.66). Srinivas et al., (1996) reported maximum florets per spike (59.0) in Suvasini, Biswas et al., (2002) and Chaturvedi et al., (2011) reported (42.0 and 55.50 florets per spike) in Shringar, Singh (2004) and Prakash et al., (2013) reported maximum florets per spike in Prajwal supported present findings. Among the single cultivars the highest duration of spike was recorded for Arka Nirantara (26.83 days) which was followed by Phule Rajani (26.00days). The minimum duration of spike was recorded for Calcutta Single I (18.33 days) and Jorhat Collection (18.33 days). Vase life of spike is a very important character for a good cut flower. 
Table.1 Morphological characters of 14 tuberose cultivars

\begin{tabular}{|c|c|c|c|c|c|c|c|c|c|c|}
\hline & $\begin{array}{l}\text { Plant } \\
\text { height } \\
(\mathrm{cm})\end{array}$ & $\begin{array}{c}\text { Leaves } \\
\text { per plant }\end{array}$ & $\begin{array}{c}\text { Days to } \\
\text { bulb } \\
\text { sprouting }\end{array}$ & $\begin{array}{c}\text { Days to } \\
\text { spike } \\
\text { emergence }\end{array}$ & $\begin{array}{c}\text { Spike } \\
\text { length } \\
(\mathrm{cm})\end{array}$ & $\begin{array}{c}\text { Rachis } \\
\text { length } \\
\text { (cm) }\end{array}$ & $\begin{array}{c}\text { No of } \\
\text { florets per } \\
\text { spike }\end{array}$ & $\begin{array}{c}\text { Duration of } \\
\text { spike } \\
\text { (days) }\end{array}$ & $\begin{array}{c}\text { Vase life } \\
\text { of spike } \\
\text { (days) }\end{array}$ & $\begin{array}{c}\text { Yield of } \\
\text { florets per } \\
\text { spike(g) }\end{array}$ \\
\hline Hyderabad Single & 74.00 & 55.33 & 12.50 & 76.17 & 70.50 & 41.00 & 33.83 & 23.83 & 11.67 & 30.67 \\
\hline Calcutta Single I & 91.83 & 54.50 & 14.83 & 79.67 & 84.17 & 45.83 & 36.00 & 18.33 & 9.67 & 32.01 \\
\hline Calcutta Single II & 79.33 & 47.16 & 15.50 & 82.16 & 68.50 & 41.00 & 27.67 & 19.50 & 10.83 & 24.21 \\
\hline Arka Nirantara & 104.30 & 67.50 & 12.17 & 74.83 & 87.83 & 59.00 & 36.83 & 26.83 & 12.67 & 47.78 \\
\hline Prajwal & 102.00 & 57.00 & 13.50 & 76.50 & 75.17 & 51.83 & 35.16 & 25.17 & 12.50 & 47.60 \\
\hline Shringar & 96.83 & 49.33 & 12.50 & 78.00 & 83.17 & 54.83 & 36.67 & 22.67 & 12.17 & 43.96 \\
\hline Jorhat Collection & 76.83 & 62.17 & 15.67 & 79.67 & 78.66 & 47.00 & 31.33 & 18.33 & 8.67 & 23.04 \\
\hline Guwahati Single & 81.00 & 76.33 & 16.50 & 79.50 & 77.96 & 41.17 & 33.83 & 19.00 & 8.33 & 27.21 \\
\hline Hajo Locale & 91.66 & 69.00 & 16.00 & 78.67 & 73.67 & 38.16 & 31.17 & 19.33 & 8.67 & 23.09 \\
\hline Maxican Single & 92.16 & 50.67 & 15.50 & 79.50 & 80.83 & 50.83 & 36.33 & 23.67 & 12.17 & 46.36 \\
\hline Phule Rajani & 69.99 & 54.50 & 14.16 & 80.16 & 81.83 & 45.17 & 33.00 & 26.00 & 10.00 & 31.22 \\
\hline Sikkim Selection & 94.83 & 42.00 & 16.00 & 81.00 & 72.83 & 49.50 & 23.66 & 18.50 & 8.00 & 17.38 \\
\hline Bidhan Rajani I & 86.16 & 49.67 & 14.33 & 78.00 & 63.67 & 40.33 & 35.16 & 27.67 & 11.83 & 34.73 \\
\hline Bidhan Rajani II & 80.83 & 42.83 & 16.17 & 77.50 & 53.67 & 36.33 & 30.83 & 21.83 & 12.17 & 43.08 \\
\hline CD at $5 \%$ & 9.66 & 12.84 & 1.53 & 1.59 & 6.95 & 7.41 & 4.66 & 2.67 & 1.61 & 6.38 \\
\hline
\end{tabular}


The preference of the consumer depends on the vase life of cut spike along with other good qualities of spike like colour of florets, spike length and the number of florets per spike. Among the single cultivars the highest vase life of spike was recorded for Arka Nirantara (12.67 days) which was at par with Shringar (12.17 days), Mexican Single (12.17 days), Bidhan Rajani II (12.17days), and Prajwal (12.50 days). The minimum vase life of spike was recorded for Sikkim Selection (8.00 days). The variation in vase life of spike might be primarily governed by the genetic makeup of the varieties. These results were also experimentally supported by the findings of Mahato et. al (2016). Among the single cultivars the highest yield of florets per spike was recorded for Arka Nirantara (47.78g)which was at par with Prajwal (47.60g), Mexican Single (46.36g), Shringar (43.96g) and Bidhan Rajani II (43.08g). The lowest yield of florets per spike was recorded for Sikkim Selection (17.38g).

Conclusion of the study is as follows:

Therefore from the experiment it is revealed that the cultivar Arka Nirantara showed highest mean performance for maximum growth and flower characters. So Arka Nirantara can be recommended along with Hyderabad Single, Shringar and Prajwal for successful cultivation in Assam condition.

\section{References}

Bankar, G. J., Mukhopadhyay, A.1980. Varietal trial on tuberose (Polianihes tuberose L.). South Indian Hortic.,28, 150-151.

Benschop, M. 1993. Polianthes. In: The Physiology of Flower Bulbs, Kamenetsky, R. and Okubo, $\mathrm{H}$. (Eds);Elsevier Publ., Amsterdam, Netherlands, pp 589-601.

Biswas, B., Kumar, N. and Bhattacharya, S.K.
2002. All India Coordinated Research Project on Floriculture. Technical Bulletin no. 21, ICAR Publications, New Delhi, p 25.

Chaturvedi, A.,Kandpal, K. and Saran, L.P. 2011. Screening of tuberose (Polianthes tuberosa L.) cultivars under agroclimatic conditions of Allahabad. Haryana J. Hortic. Sci., 40,145-147.

Dimri, S., Punetha, P., Bohra, M. and Tanuja. 2017. Screening of suitable germplasm of tuberose (Polianthes tuberosa L.) for mid hill conditions of Garhwal Himalaya. Int.J.Agric.Sci.Res., 7, 499506.

Mahawer, N.L., Bairwa, L.H. and Shukla, K.A. 2013. Field performance of tuberose cultivars for growth, floral and economic characters under sub-humid southern plains and Aravalli hills of Rajasthan. Indian J. Hortic., 70, 411416.

Mahato. P., Punetha, P. and Rana, D.K. 2016. Evaluation of tuberose genotypes for vegetative, floral and bulb yielding attributes under the valley conditions of Garhwal Himalayas. Int. J. Agric. Sci., 8, 3522-3524.

Pal, K. M. and Mitra, M. 2008. Performance of tuberose (Polianthes tuberosa L.) varieties in the plains of West Bengal. International seminar on Multidisciplinary Approaches in Angiosperm Systematics, Oct. 11-13, 862-864.

Patil, J.D., Patil, B.A., Chougule, B.B. and Bhat, N.R. 1987. Performance of different tuberose cultivars under Pune conditions. Curr. Rep.,3,118.

Prakash, S., Arya, K., Singh, K.R. and Singh, P.K.2015. Varietal performance of tuberose in Muzaffarnagar under western plain zone condition. Asian J. Hortic., 10, 149-152.

Ramachandrudu, K. and Thangam, M. 2009. Performance of tuberose (Polianthes 
tuberosa L.) cultivars in Goa. J. Hortic. Sci., 4, 76-77.

Singh, K. P. 1995. Improved production technologies for tuberose (Polianthes tuberosa L.). Agric. Rev., 16,141-166.

Singh, K.P. 2004. Performance of single petalled tuberose cultivars under Delhi condition. National symposium on Recent Trends and Future Strategies in Ornamental Horticulture, Dharwad, Dec. 1-4, 18.

Singh, P.K. and Singh, C.M. 2013. Evaluation of double petalled cultivars of tuberose
(Polianthes tuberose Linn.) under Delhi condition. Asian J. Hortic., 8, 512-514.

Singh, A. K. and Jonah, D. 2017. Evaluation on performance and superiority of tuberose (Polianthes tuberosa L.) cultivars for growth and flowering under North Indian plain. Environ. Ecol., 35, 341-345.

Srinivas, M., Murthy, N., and Chandravadana,M.V.1996. Genotypic and seasonal variation for concrete content in tuberose (Polianthes tuberosa L.). J Essent. Oil. Res., 8, 541-542.

\section{How to cite this article:}

Kishalayee Gogoi and Madhumita Choudhury Talukdar. 2020. Field Performance of Single Cultivars of Tuberose for Growth and Floral Characters under Assam Condition. Int.J.Curr.Microbiol.App.Sci. 9(04): 1936-1941. doi: https://doi.org/10.20546/ijcmas.2020.904.230 